Proceedings of the Second Annual Forestry Symposium 1996: Management and Sustainable Utilization of Forest Resources, Sri Lanka, 6-7 December 1996. (Eds. Amarasekera, HS, Ranasinghe, D M S HK and Finlayson. W). Published by Department of Forestry and Environmental Science. University of Sri Jayewardenepura, Sri Lanka (1998)

\title{
STATUS OF FORESTRY DEVELOPMENT IN EIGHT IRRIGATION SCHEMES IN MONARAGALA DISTRICT
}

\author{
J. Handawela \\ Land Use Consultant, Mithrabhoomi - (Organization for Land Friendly Land Use ). \\ Rajagiriya
}

\begin{abstract}
A survey found that "Forestry" was practised on the irrigated smallholdings only to a limited extent, mainly for the production of food. There were very few relict trees from the former forest, but there was some planting of commercial timbers, mainly teak and halmilla (Berrya cordifolia) and of plants used in indigenous medicine. Of nonwood forest products, fodder and thatching grass are the most important. No bee-kecpers were found in the sample.
\end{abstract}

\section{Introduction}

A survey of eight irrigation schemes was conducted in 1995-96, to provide baseline infonmation for the plamning of a proposed development programme under the Monaragala District Irrigation and Community Development Project. Although it was originally intended to be generally of a socio-economic nature. the terms of reference had sufficient flexibility for it to include forestry, which has to be viewed as an important socio-economic activity, even in irrigation projects.

\section{Study area, methods}

The eight schemes are:

- Dehiattawela, a large anicut scheme built in 1877 in the Bibile and Medagama Secretarial Divisions (SDs).

- Monerawana, a small anicut scheme partly developed in 1952 in Madagana SD. but not completed becaluse of management difficulties.

- Etimole. a large tank and anicut scheme developed in 1952 in Siyambalanduwa $\mathrm{SD}$, based on the renovation of an ancient tank and the construction of a new anicut.

- Kotiyagala, a large scheme opened in 1951 in Siyambalanduwa SD by renovating a medium-sized ancient tank. 
- Kumbukkana, a large anicut scheme on the Kumbukkan Oya, first restored in the 1870s and further expanded in 1935 and 1955. The greater part of the scheme falls within Buttala SD.

- Yudaganawa, a medium-sized scheme in Buttala SD, restored in 1953, supported by an anicut on the Menik Ganga, and a tank.

- Handapanagala, a large scheme in Wellawaya SD, developed primarily for coconut cultivation, associated with a large tank that was restored in 1956.

- Dambe Wewa, a newly constnucted, medium-sized, tank-based scheme, opened in the 1950s in Wellawaya SD.

The survey used available information and easily observable field reconnaissance data to describe each scheme. Subdivisions were recognized, based on the internal spatial variation. A sample of families was selected. comprising about $10 \%$ of the total population. The selection was based on the structural arrangement of the subdivisions and the vertical socioeconomic stratification of the population within subdivisions, making certain that every spatial subdivision and every important stratum of society were appropriately represented.

The survey was conducted by trained field enumerators, working under professional guidance and supervision. using a "participatory nural assessment" procedure. Field maps were used to locate sample families and to record physical information. Questionnaires were used to assist in the enumeration. The information collected was summarized and processed separately for each scheme.

\section{Results and discussion}

Figure 1 shows the location of the schemes in relation to relief and agro-ecology. All the schemes fall below the 1000 -foot $(300 \mathrm{~m})$ contour and within the drier agroecological regions (IL2 or DL1). They range in size from 152 to 3199 ha, and the proportion of the command area to the total area varies between 17 and $25 \%$. Their population ranges from 350 to 1500 families. The settlers have up to three types of land holdings: irrigated paddy land, residential plots without irrigation facilities, and a chena plot. Their forestry practices are confined to the residential plots. The land holdings are small (Table 1).

The schemes were primarily designed for paddy cultivation, except for Handapanagala which was planned mainly for coconuts. The farmers' preferred crop in the residential plots is coconuts. The production of both paddy and coconuts is not high (Table 1). In any one scheme, up to $46 \%$ of the farmers have no opportunity to produce paddy. As many again do not produce enough paddy for all of their home consumption. Some $7-35 \%$ of families produce cnough for home consumption, and a number varying widely from scheme to scheme $(11-86 \%)$ produce a surplus. Coconut productiion is not even as good. There is a need to change from what is almost a monoculture of paddy to a system of diversified land use. Forestry is one possibililty 

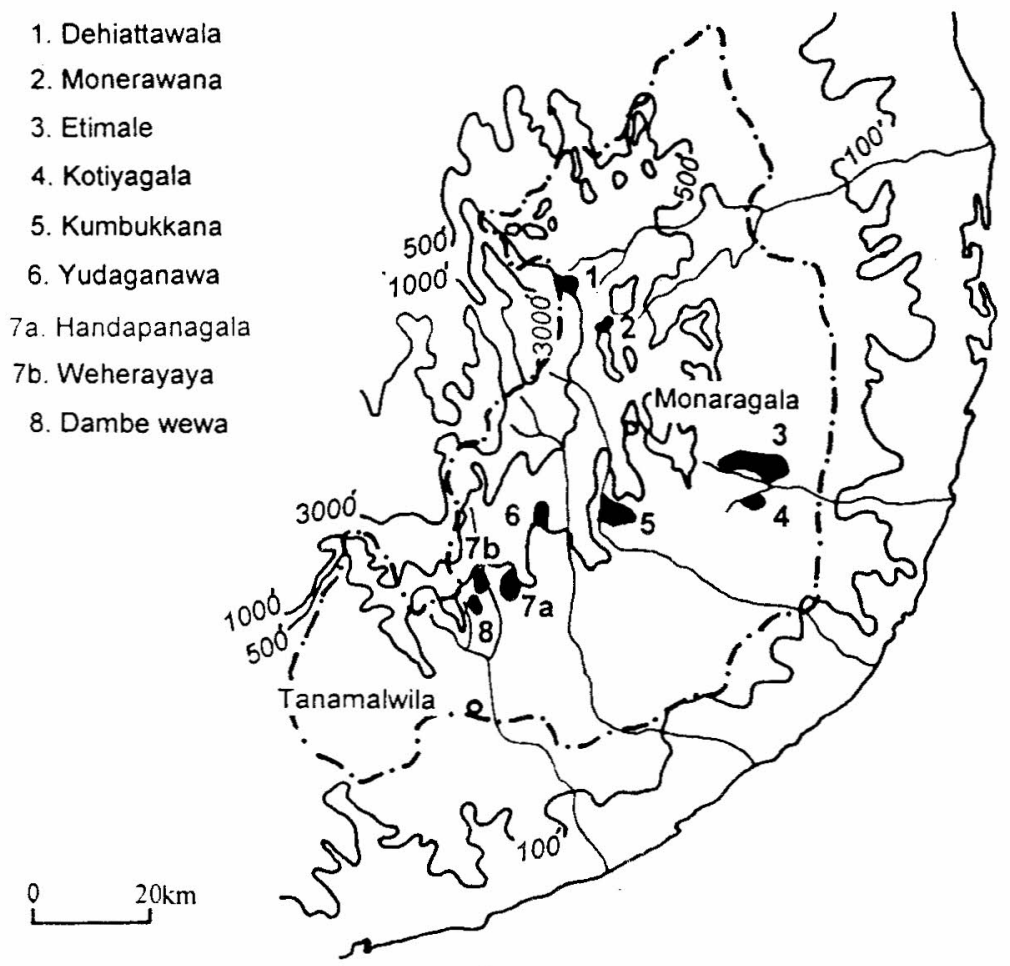

Figure 1: Regional relief in and around the district and the location of the irrigation whemes

Forestry, limited to the residential piot, has a low priority for the farmers, and has nad aimost no institutional attention. The small size of the residential plots (Table 1) to which the limited forestry is confined implies a need for very intensive operations and great efficiency in management. but this need does not seem to be satisfied.

In view of the high-intensity rainfall experienced in the area, mechanical conservation measures are very necessary. But on the different schemes, $39 \%$ to $93 \%$ of the holdings do not use any such measures. Up to $32 \%$ of the holdings have no live fence on the boundary. and most of the existing live fences do not offer effective protection against stray cattle (Table 2). Little of the technology that is needed for satisfactory silviculture is available. Of the 500 families surveyed only one had a university graduate in agriculture. and he had emigrated to the wet zone. There are no diploma holders in agriculture or forestry. A person with the ability to trace a contour is hard to come by: Competence in techniques like budding and grafting is very low and there are no nursenmen. The younger householders are not familiar with the indigenous forest tree species, some finding it difficult to identify even a very common species such as milla (Vitex altissima). 
Handawela

Table 1 : Areat of irrigation schemes and individual land holdings, and crop production

\begin{tabular}{lccccccccc}
\hline & Dehi & Mon & Eti & Kot & Kum & Yud & Han & Dam & Tot/av \\
\hline $\begin{array}{l}\text { Total area (ha) } \\
\begin{array}{l}\text { Designed command } \\
\text { area (hia) }\end{array}\end{array}$ & 628 & 372 & 1737 & 980 & 2556 & 248 & 3199 & 152 & 9972 \\
$\begin{array}{l}\text { Presently } \\
\text { inigated (ha) }\end{array}$ & 506 & 70 & 517 & 322 & 728 & 178 & 4324 & 115 & 2860 \\
Families & 1043 & 350 & 1163 & 420 & 1800 & 440 & 1500 & 475 & 7191
\end{tabular}

Average plot size (ha)

$\begin{array}{llllllllll}\text { Residential } & 0.64 & 0.72 & 0.52 & 0.56 & 0.48 & 0.6 & 0.72 & 0.64 & 0.6 \\ \text { Padddy land } & 0.48 & 0.2 & 0.44 & 0.76 & 0.4 & 0.4 & 0.28 & 0.24 & 0.4\end{array}$

Residential plot size classes, \% fanilies

\begin{tabular}{|c|c|c|c|c|c|c|c|c|c|}
\hline 0.4 hat & 34 & 24 & 32 & 10 & 42 & 29 & 22 & 9 & 25 \\
\hline $0.4-0.8$ ha & 48 & 51 & 59 & 87 & 51 & 71 & 40 & 79 & 61 \\
\hline $0.8-1.6 h a$ & 15 & 15 & 8 & 2 & 7 & 0 & 35 & 12 & 12 \\
\hline 1.6 hat & 3 & 9 & 1 & 0 & 1 & 0 & 2 & 0 & 2 \\
\hline \multicolumn{10}{|c|}{ Paddy production status, \% lamilies } \\
\hline No production & 15 & 9 & 6 & 0 & 25 & 2 & 45 & 46 & 18 \\
\hline luaderpuate & 16 & 45 & 10 & 5 & 14 & 4 & 19 & 28 & 18 \\
\hline Adequate & 15 & 24 & 12 & 35 & 15 & 7 & 13 & 14 & 17 \\
\hline Sumplus & 55 & 21 & 72 & 60 & 46 & 86 & 24 & 11 & 47 \\
\hline
\end{tabular}

Coconut production status, $\%$ familias

\begin{tabular}{llllllllll} 
Inadequate & 43 & 42 & 25 & 25 & 39 & 36 & 57 & 90 & 45 \\
Adequate & 30 & 33 & 40 & 35 & 42 & 52 & 26 & 10 & 33 \\
Surplus & 27 & 24 & 34 & 40 & 19 & 12 & 17 & 0 & 22 \\
\hline
\end{tabular}

The commonest form of forestry is the growing of food trees (Table 2). Coconuts are favoured by most of the people and where they are grown there are usually more than ten trees per residential plot; the number decreases with decreasing rainfall and availability of irrigation water. Jak (Arlocarpus heterophyllus) is the next most common. While coconut has been planted, and some attention given to spacing, jak generally grows by natural dispersal; the trees are distributed in the home compound and along the boundary of the land. There are 59 jak trees per residential plot. Mango trees are even fewer; they too grow naturally without being planted or trained. Moisture loving species like bread fruit (Artocarpus nobilis) and kitul palms (Caryola urens) are confined to the relatively wetter Dehiattawela and Monerawana schemes. The species adapted to drier conditions, such as wood apple (Feronia limonia), drumstick (Moringa oleifera), and tamarind (Tamarindus indicus) are, naturally, found in greater numbers in the drier areas. 


Dehi Mon Eti Kot Kum Yud Han Dam Av.

Presence of mechanical conservation measures, \% families

$\begin{array}{llllllllll}\text { Yes } & 40 & 61 & 31 & 17 & 61 & 33 & 7 & 14 & 33 \\ \text { No } & 60 & 39 & 69 & 83 & 39 & 67 & 93 & 86 & 67\end{array}$

Live fence, $\%$ families

$\begin{array}{lccccccccc}\begin{array}{l}\text { Absent } \\ \begin{array}{l}\text { Present and } \\ \text { eflective }\end{array}\end{array} & 2 & 6 & 4 & 12 & 9 & 0 & 23 & 32 & 11 \\ & 14 & 15 & 5 & 3 & 48 & 19 & 16 & 2 & 15\end{array}$

Trees (per plot, $c=>10, m=5-9, \mathrm{f}=1-4, \mathrm{n}=0$, na = no information; ${ }^{*}$ food as well as wood)

$\begin{array}{llllllllll}\text { *bread fruit } & \mathrm{f} & \mathrm{f} & \mathrm{n} & \mathrm{n} & \mathrm{n} & \mathrm{n} & \mathrm{n} & \mathrm{n} & \mathrm{n} \\ \text { *kitul } & \mathrm{f} & \mathrm{f} & \mathrm{n} & \mathrm{n} & \mathrm{n} & \mathrm{n} & \mathrm{n} & \mathrm{n} & \mathrm{n} \\ \text { *coconut } & \mathrm{c} & \mathrm{c} & \mathrm{c} & \mathrm{c} & \mathrm{c} & \mathrm{c} & \mathrm{m} & \mathrm{f} & \mathrm{c} \\ \text { *jak } & \mathrm{m} & \mathrm{m} & \mathrm{m} & \mathrm{m} & \mathrm{m} & \mathrm{m} & \mathrm{m} & \mathrm{f} & \mathrm{m} \\ \text { *mango } & \mathrm{f} & \mathrm{f} & \mathrm{m} & \mathrm{m} & \mathrm{m} & \mathrm{m} & \mathrm{m} & \mathrm{f} & \mathrm{m} \\ \text { *lime } & \mathrm{m} & \mathrm{m} & \mathrm{m} & \mathrm{m} & \mathrm{m} & \mathrm{f} & \mathrm{f} & \mathrm{m} & \mathrm{m} \\ \text { *wood apple } & \mathrm{n} & \mathrm{n} & \mathrm{f} & \mathrm{f} & \mathrm{f} & \mathrm{f} & \mathrm{f} & \mathrm{f} & \mathrm{f} \\ \text { *drum stick } & \mathrm{n} & \mathrm{n} & \mathrm{f} & \mathrm{f} & \mathrm{n} & \mathrm{f} & \mathrm{f} & \mathrm{n} & \mathrm{f} \\ \text { *tamarind } & \mathrm{n} & \mathrm{n} & \mathrm{n} & \mathrm{f} & \mathrm{n} & \mathrm{f} & \mathrm{f} & \mathrm{f} & \mathrm{f} \\ \text { teak } & \mathrm{m} & \mathrm{r} & \mathrm{c} & \mathrm{m} & \mathrm{m} & \mathrm{m} & \mathrm{f} & \mathrm{m} & \mathrm{m} \\ \text { halmilla } & \mathrm{n} & \mathrm{n} & \mathrm{m} & \mathrm{c} & \mathrm{n} & \mathrm{m} & \mathrm{n} & \mathrm{m} & \mathrm{f} \\ \text { margosa } & \mathrm{n} & \mathrm{f} & \mathrm{m} & \mathrm{n} & \mathrm{f} & \mathrm{n} & \mathrm{n} & \mathrm{f} & \mathrm{f} \\ \text { satin } & \mathrm{n} & \mathrm{n} & \mathrm{r} & \mathrm{n} & \mathrm{f} & \mathrm{f} & \mathrm{f} & \mathrm{f} & \mathrm{f} \\ \text { milla } & \mathrm{f} & \mathrm{f} & \mathrm{f} & \mathrm{f} & \mathrm{f} & \mathrm{n} & \mathrm{f} & \mathrm{f} & \mathrm{f} \\ \text { ketakella } & \mathrm{f} & \mathrm{f} & \mathrm{n} & \mathrm{f} & \mathrm{f} & \mathrm{n} & \mathrm{f} & \mathrm{f} & \mathrm{f} \\ \text { kon } & \mathrm{f} & \mathrm{n} & \mathrm{n} & \mathrm{n} & \mathrm{n} & \mathrm{n} & \mathrm{f} & \mathrm{f} & \mathrm{f} \\ \text { damaniya } & \mathrm{n} & \mathrm{n} & \mathrm{f} & \mathrm{f} & \mathrm{na} & \mathrm{na} & \mathrm{f} & \mathrm{f} & \mathrm{f} \\ \text { suriya mara } & \mathrm{na} & \mathrm{na} & \mathrm{na} & \mathrm{na} & \mathrm{na} & \mathrm{f} & \mathrm{na} & \mathrm{na} & \mathrm{na} \\ \text { kolon } & \mathrm{na} & \mathrm{na} & \mathrm{na} & \mathrm{na} & \mathrm{na} & \mathrm{na} & \mathrm{na} & \mathrm{f} & \mathrm{na} \\ \text { palu } & \mathrm{n} & \mathrm{n} & \mathrm{n} & \mathrm{n} & \mathrm{n} & \mathrm{n} & \mathrm{n} & \mathrm{n} & \mathrm{n} \\ \text { kumbuk } & \mathrm{n} & \mathrm{n} & \mathrm{n} & \mathrm{n} & \mathrm{n} & \mathrm{n} & \mathrm{n} & \mathrm{n} & \mathrm{n} \\ \text { ebony } & \mathrm{n} & \mathrm{n} & \mathrm{n} & \mathrm{n} & \mathrm{n} & \mathrm{n} & \mathrm{n} & \mathrm{n} & \mathrm{n}\end{array}$

Other uses, \% tamilies (beekeeping recorded every where as nil)

$\begin{array}{llllllllll}\text { Cattle } & 12 & 12 & 25 & 12 & 5 & 0 & 10 & 18 & 12 \\ \text { Illuk thatch } & 5 & 16 & 25 & 30 & 3 & 5 & 33 & 57 & 22\end{array}$

Fuelwood self-sufficiency, \% families

$\begin{array}{lllllllll}37 & 22 & 19 & 25 & 43 & 81 & 73 & 26 & 41\end{array}$

Improved hearth use, \% families

$15 \quad 13$

$\begin{array}{llll}13 & 25 & 0 & 1\end{array}$

$10 \quad 60 \quad 0$ 
The timber tree species found on the settlement holdings can be considered under three categories:

- Residual forest species. These include satin (Chloroxylon swietenia), kon (Schleichera oleosa), ketakella (Bridelia retusa), milla (Vitex altissima), kolon (Adina cordifolia), damunu (Grewia daminie), which propagate as root and stump sprouts. These are not planted at all by the people, nor are they institutionally promoted.

- Commercial timber species. Teak (Tectona grandis) and halmilla (Berrva cordifolia).

- Rural timber species. Margosa (Azadirachta indica) and suriya mara (Albizia lebbech). Margosa $(=$ neem) is a medicinal plant as well as a timber tree, and is naturally propagated from seed. Suriya mara is planted in small numbers.

It is the two "commercial species" that are most common. Residual species from indigenous forest are declining in numbers, with no planting or attention to cxisting trees. Hardly any settlement plot has trees of palu (Nanilkara hexandra). kumbuk (Terminalia arjuna), mee (A Jadhuca longifolia) or other traditional forest timber species.

Maila (Bauhimia racemosa) is the forest fodder tree best suited to the area, with an admirable ability to withstand drought. It is used by the people as fodder for livestock especially during severe droughts, but is not being grown or promoted.

Cattle are kept mostly as free grazing herds, depending mainly on bush and wasteland. The percentage of families who kecp more than five cattle is directly related to the availability of wastcland in and around the schemes.

Illuk grass (Imperata cylindrica) has been an important forest byproduct. used as thatching for nural cottages. Its use decreases with increasing urbanization, from remote Dambe Wewa and Kotiyagala to modernizing Kumbukkana.

The proportion of families self sufficient in fuelwood from their own settlement plot is low, except in Yudaganawa and Handapanagala, where the residential plots are comparatively large. Fuelwood has not been a major development issue either for the authorities or the settlers. The settlers, or rather the housewives, supplement their fuelwood needs mainly by collecting from the nearby bush, reservations, and the forest. A very few, in Dehiatlawela and Kumbukkana, buy fuelwood. An improved fuel-saving wood-burning stove has bcen promoted in the region, but the adoption rate is low, the highest being $25 \%$ at Etimole

No settlers in the sample kept bees in their plots. Nor was it possible to find any settler who collected honcy professionally from the forest 


\section{Conclusions}

Irrigation has been the overriding concern. and forestry has not been viewed as a development objective. The traditional methods of forest use by the local people, for shifting cultivation, rearing of cattle, and the harvesting of forest products like illuk grass and honey have been either discouraged or at least denied institutional suppon. Institutional apathy towards traditional forestry has not been replaced by any alternative development of modern forestry.

Irrigation must not be viewed only as a basis for the production of seasonal crops. The hydrological and habitat stabilization brought about by irrigation could be used for forestry development as well, not in competition with seasonal crops, but as a very useful complementary pursuit. Meanwhile. the technology needed for effective use of forestry in development is lacking. 